\title{
KLASIFIKASI METODE NAIVE BAYES UNTUK KELANCARAN PEMBAYARAN KREDIT LEASING SEPEDA MOTOR
}

\author{
Fakultas Teknologi Informasi \\ Universitas Islam Kalimantan Muhammad Arsyad Al Banjari Banjarmasin \\ Budi Ramadhani \\ Budiramadhani99@gmail.com
}

\begin{abstract}
Permasalahan yang sering timbul pada perusahaan leasing adalah banyaknya pelanggan yang mengalami kesulitan dalam membayar cicilannya, maka diperlukan suatu sistem yang dapat mengklasifikasikan konsumen yang masuk ke grup saat ini, kelompok kurang lancar dan konsumen yang masuk ke dalam kelompok tidak lancar dalam membayar cicilan cicilan sepeda motor. Sehingga sewa bisa mengatasi masalah awal. Sebuah perusahaan leasing harus memiliki data yang sangat besar. Banyak yang tidak menyadari bahwa pengolahan data data tersebut bisa memberikan informasi seperti klasifikasi data konsumen yang akan bergabung dengan perusahaan itu sendiri. Penerapan teknik data mining diharapkan dapat memberikan informasi yang berguna mengenai teknik klasifikasi data konsumen yang akan bergabung dengan grup saat ini, kelompok kurang lancar atau tidak lancar dalam membayar premi.

Langkah penelitian meliputi pengumpulan dan pengujian data algoritma Naive Bayes. Dalam penelitian ini, kumpulan data yang digunakan adalah Customer, Employment, Number of Children, Status Houses, region, angsuran.

Penelitian ini bertujuan untuk mengetahui Klasifikasi Metode Naive Bayes Berbasis Metode PSO Untuk Smooth Credit Leasing Motorcycles

Hasil percobaan menggunakan metode Naïve Bayes untuk mengukur pengukuran lancar dan tidak lancar yang diperoleh pengukuran memiliki Naïve Baiyes tertinggi adalah 96,43\% namun sekarang metode algoritma Naive Bayes Particle Swarm Optimization sebesar $96,88 \%$, adalah akurasi namun baik
\end{abstract}

Keywords: Current and Non Current, Naive Bayes Method Based PSO

\section{PENDAHULUAN}

Data yang ada dianalisis menggunakan algoritma Naive Bayes. Naive Bayes merupakan salah satu metode pada probabilistic reasoning. Algoritma Naive Bayes bertujuan untuk melakukan klasifikasi data pada kelas tertentu, kemudian pola tersebut dapat digunakan untuk memperkirakan nasabah yang bergabung, sehingga perusahaan bisa mengambil keputusan menerima atau menolak calon nasabah tersebut. Guna memperoleh nilai prediksi yang akurat diperlukan 
metode yang tepat agar dapat menghasilkan nilai prediksi dengan tingkat akurasi tinggi. Saat ini banyak permasalahan nyata yang diselesaikan dengan metode softcomputing dari pada hardcomputing.

\section{TUJUAN PENELITIAN}

Berdasarkan latar belakang maka penelitian ini bertujuan "Untuk mengetahui Klasifikasi Metode Naive Bayes Untuk Kelancaran Pembayaran Kredit Leasing Sepeda Motor.

\section{MANFAAT PENELITIAN}

Hasil penelitian ini diharapkan dapat membantu pihak terkait, yang dalam hal ini adalah pihak perusahaan dalam membuat perencanaan Metode Naive Bayes Untuk Kelancaran Pembayaran Kredit Leasing Sepeda Motor dengan hasil yang lebih baik.

\section{KLASIFIKASI NAIVE BAYES}

Model dalam klasifikasi mempunyai arti yang sama dengan kotak hitam, dimana ada suatu model yang menerima masukan, kemudian mampu melakukan pemikiran terhadap masukan tersebut dan memberikan jawaban sebagai keluaran dari hasil pemikirannya.

1. Model yang sudah dibangun pada saat pelatihan kemudian dapat digunakan untuk memprediksi label kelas baru yang belum diketahui. Dalam pembangunan model selama proses pelatihan tersebut diperlukan suatu algoritma untuk membangunnya, yang disebut algoritma pelatihan (learning algorithm).

2. Prediksi Klasifikasi adalah pemprosesan untuk menemukan sebuah model (atau fungsi) yang menjelaskan dan mencirikan konsep atau kelas data, untuk kepentingan tertentu, yang bisa menggunakan pemodelan untuk memprediksi kelas objek yang label nya tidak diketahui.

Tidak seperti klasifikasi dan prediksi, yang menganalisa pelabelan objek data, clustering menganalisis objek data tanpa mengkonsultasikan label kelas yang dikenal. Secara umum label kelas bukan didapat dalam pengolahan data sederhana kerena mereka tidak tahu bagaimana memulainya. Clustering bisa digunakan untuk megenerate label.

\section{PENELITIAN}

\section{Metode Pengolahan Data Awal}

Data yang didapatkan dari Perusahaan leasing di Wilayah Banjarmasin, Banjarbaru dan Martapura mengambil data pembayaran kredit sepeda motor dengan atribut No LOAN Nasabah, nama nasabah, merk kendaraan.

\section{Metode Yang Diusulkan}

Metode yang diusulkan untuk menentukan kelancaran pembeyaran kredit sepeda motor Perusahaan leasing di Wilayah Banjarmasin, Banjarbaru dan Martapura adalah algoritma algoritma naive bayes. 


\section{Eksperimen dan Pengujian Model/Metode}

Metode yang telah dikembangkan dalam penelitian ini akan diterapkan pada data nasabah Perusahaan leasing di Wilayah Banjarmasin, Banjarbaru dan Martapura tahun 2014 melalui suatu model simulasi menggunakan $\mathrm{R}$ Software atau RapidMiner. Sebanyak $90 \%$ dengan metode algoritma naive bayes.

\section{Tabel. 3.1 Data Nasabah}

\begin{tabular}{|c|c|c|c|c|c|c|c|c|}
\hline \multirow[b]{2}{*}{1.0} & \multirow[b]{2}{*}{ P.rul } & \multirow[b]{2}{*}{ 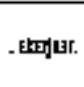 } & \multirow[b]{2}{*}{ 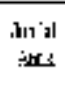 } & \multirow[b]{2}{*}{$\begin{array}{l}\text { Jaus s } \\
\text { Janat. }\end{array}$} & \multirow[b]{2}{*}{ لدיד1':" } & \multicolumn{2}{|c|}{ A15emm } & \multirow[b]{2}{*}{ J'thed } \\
\hline & & & & & & Tाтr & $\begin{array}{l}\text { Tütut } \\
\text { |esal }\end{array}$ & \\
\hline : & ند ו & $\therefore$ & . & $\therefore$ & $\therefore$ & $\therefore$ & & -rar \\
\hline$i$ & 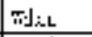 & $\Xi$ & : & $\vdots$ & $\therefore$ & & $\Xi$ & TA:Se: \\
\hline$=$ & $\therefore-i t$ & : & $\mathrm{I}$ & $\therefore$ & $:$ & 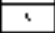 & & irr \\
\hline 1 & $E: \pi$ & : & $\cdot$ & $\therefore$ & $\therefore$ & 3 & & ${ }^{\circ} \mathrm{mr}$ \\
\hline$?$ & I차:1:r & $=$ & $\mathrm{I}$ & 2 & 7 & 2 & . & ara \\
\hline$\vdots$ & lic...: & $I$ & : & $:$ & $:$ & . & $\Xi$ & Is:-ix: \\
\hline . & $\therefore(k \leq x$ & 1 & $:$ & $=$ & $\dot{i}$ &. & $=$ & $\mid x \leq 2$ - $x \leq \leq$ \\
\hline$:$ & .:xi:s & : & $:$ & 2 & $\dot{s}$ & $\cdot$ & 2 & 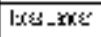 \\
\hline, & .1: & $\therefore$ & $:$ & $\dot{\dot{x}}$ & 2 & $\therefore$ & . & - IRI \\
\hline$: 1$ & $\mathrm{H}:-1:=$ & $z$ & . & $\therefore$ & $=$ & $\therefore$ & & -rar \\
\hline 1 & in.5 & - & . & $\vdots$ & ? & & $=$ & 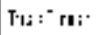 \\
\hline ? & sitri & • & 1 & $\therefore$ & $\therefore$ & s & & $\mathrm{mr}$ \\
\hline$i$ & id $x:$ & : & I & i & i & $s$ & . & irro \\
\hline$\because$ & : & $\therefore$ & $\vdots$ & $\dot{\Lambda}$ & $\xi$ & $\therefore$ & . & $\therefore x_{1}$ \\
\hline 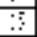 & sive ste & $\vdots$ & $\vdots$ & $\dot{s}$ & $\because$ & 2 & $\cdot$ & IMY \\
\hline$i$ & $\sum r_{r} r_{1}=1$ & 7 & 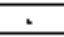 & $\because$ & $i$ & . & 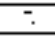 & 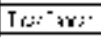 \\
\hline$i:$ & & $\ldots \ldots$ & & & & & & \\
\hline
\end{tabular}
keseluruhan ada 221 Nasabah. Dari semua data ditentukan atribut proses pengolahan data awal dimulai dari kolom Nasabah, Pekerjaan, Jumlah Anak, Status Rumah, Wilayah, Angsuran, untuk lebih jelasnya dapat dilihat tabel atribut dibawah ini :

Tabel 3.2. Atribut

\begin{tabular}{|l|l|l|l|}
\hline No & $\begin{array}{c}\text { Nama } \\
\text { Atribut }\end{array}$ & Tipe & Keterangan \\
\hline 1 & Pekerjaan & Nominal & $\begin{array}{l}\text { PNS, } \\
\text { TNI/POLRI, } \\
\end{array}$ \\
& & & $\begin{array}{l}\text { Swasta, } \\
\text { Wiraswasta }\end{array}$ \\
\hline 2 & Jumlah & Numerik & $1,2,3,4,5$ \\
& Anak & & \\
\hline
\end{tabular}

\begin{tabular}{|l|l|l|l|}
\hline 3 & $\begin{array}{l}\text { Status } \\
\text { Rumah }\end{array}$ & Nominal & $\begin{array}{l}\text { Milik Sendiri, } \\
\text { Sewa, Pinjam, } \\
\text { Ikut Orang tua }\end{array}$ \\
\hline 4 & Angsuran & Numerik & $\begin{array}{l}\text { Tepat, Tidak } \\
\text { tepat }\end{array}$ \\
\hline
\end{tabular}

Metode yang Diusulkan (Proposed Method)

Pada penelitian ini penulis mengusulkan metode Naive Bayes untuk membantu menentukan lancar dan tidak lancar pembayaran angsuran kendaraan bermotor. Metode ini dipilih karena kemampuannya untuk melakukan pengelompokkan suatu objek atau data yang belum memiliki klasifikasi, ke dalam kelas tertentu menurut kesamaan yang dimilikinya berdasarkan derajat keanggotaan dengan cara minimalisasi nilai fungsi objektifnya. Metode naïve bayes akan diimplementasikan pada penelitian ini.

\section{Eksperimen dan Pengujian Model}

Algoritma yang telah dikembangkan dalam penelitian ini akan diterapkan pada Nasabah, Pekerjaan, Jumlah Anak, Status Rumah, Wilayah, Angsuran pada saat pembayaran angsuran oleh nasabah.

Pada tahap awal dilakukan pemetaan korelasi antara nilai, data lancar dengan hasil akhir penempatan peminatan, hasilnya ditunjukan pada gambar berikut:

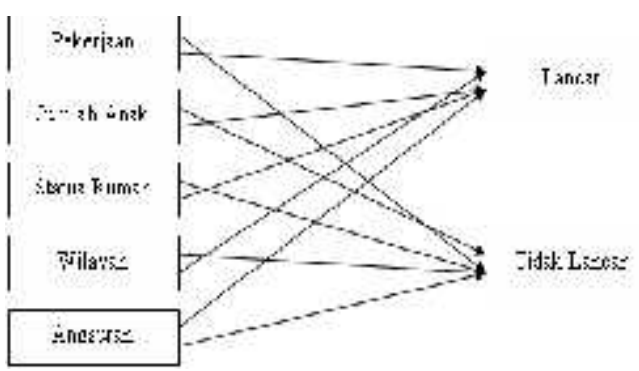


Gambar 3.1 Pemetaan antara lancer dan tidak lancar

Menentukan hasil akhir merupakan hasil yang diperoleh dari nasabah dalam membayarn angsuran yaitu lancar dan tidak lancar, ditambahkan Pekerjaan, Jumlah Anak, Status Rumah, Wilayah, Angsuran. Kemudian Data ini akan digunakan sebagai data variabel ujicoba peminatan menggunakan Metode Naïve Bayes (gambar 3.1).

\section{Evaluasi}

Evaluasi dilakukan dengan mengambil hasil prediksi dibandingkan dengan data awal yang diolah.

\section{HASIL EKSPERIMEN}

\section{Hasil Eksperimen dan Pengujian Model}

Data yang digunakan merupakan data sekunder hasil penerimaan angsuran dari nasabah tahun 2016. Data yang terkumpul kemudian dilakukan preprocessing dengan cara melakukan identifikasi dan inspeksi sejumlah atribut-atribut yang tidak relevan. Kemudian setelah diketahui sejumlah atribut yang tidak relevan maka tahap selanjutnya adalah mengeliminasi sejumlah atribut tersebut dan melakukan subtitusi data sehingga data dapat diproses dalam data mining.

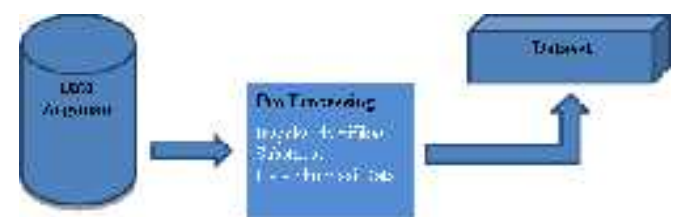

Gambar 4. 1 Proses Pre-processing
Dataset tersebut memiliki label Lancar dan Tidak Lancar 5 variabel sebagai atribut. Ada dua tipe data yaitu data nominal dan data numeric. Data nominal tersebut yang diinginkan adalah pekerjaan, status rumah dan wilayah sedangkan data numeriknya yaitu jumlah anak dan angsuran.

Hasil perhitungan data angsuran nasabah sebagai berikut :

1. Perhitungan Data Nominal

Diketahui :

- $\quad$ Tipe Data $=$ Nominal

- Pekerjaan

- Status Rumah

- Wilayah

\section{Misal :}

- $\quad E_{1}=$ Pekerjaan

- $\quad E_{2}=$ Status Rumah

- $\quad E_{3}=$ Wilayah

- $\quad$ Yes = Lancar

- $\quad$ No = Tidak Lancar

Tabel 4. 1 Perhitungan Data Nominal

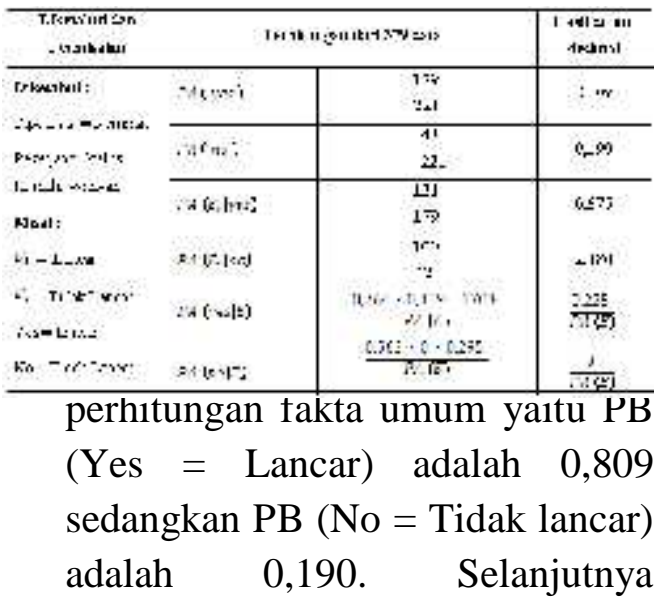


menghitung berdasarkan rumus Naive Bayes atau HMAP data training dengan hipotesa

Tabel 4. 2 Nilai rata-ratadan standar deviasi Perhitungan Data Numerik

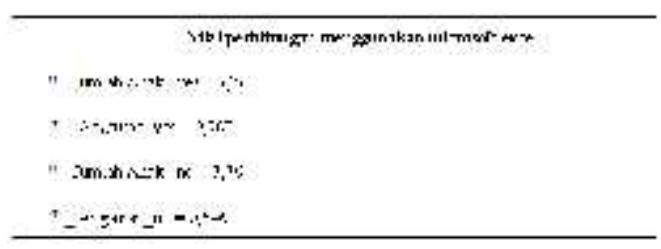

Oleh karena itu, the naïve bayes classifier predicts lancer dan tidak lancer $=$ yes for the new example.

Berdasarkan sampel data pada tabel 4.3 diatas dapat diketahui perbandingan hasil keputusan Naive Bayes dengan data original yaitu 221 data teridentifikasi akurat dan 42 yang tidak akurat.

Pada tahap pertama eksperimen dan pengujian model dilakukan dengan data original yang sebagian masih memiliki data kosong. Kemudian pengujian dilakukan menggunakan algoritma Naive Bayes dengan validasi model klasifikasi dilakukan terhadap data testing dengan teknik 10-folds cross validation.

Ketika diimplementasi menghasilkan data sebagai berikut :

Tabel 4.4 Akurasi Naive Bayes Menggunakan Data Original

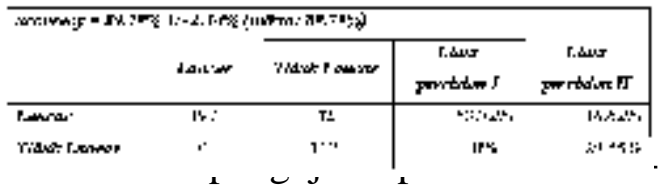
menggunakan metode Naive Bayes dengan data original tersebut didapatkan akurasi yang sudah cukup baik sekitar $84,96 \%$. Oleh sebab itu maka untuk membuat model keputusan yang baik, harus menggunakan data yang baik pula (lengkap, benar, konsisten, terintegrasi).

Dari beberapa percobaan menggunakan teknik pengisian yang berbeda, didapatkan hasil bahwa tidak semua teknik tersebut sesuai atau cocok digunakan pada data yang diuji. Hal tersebut terjadi pada percobaan menggunakan teknik minimum, maximum dan zero karena ketiga teknik tersebut tidak cocok dengan karakter nilai yang terdapat pada data yang diuji yang sebagian besar bersifat nominal sehingga ketika diimplentasikan meskipun telah menggunakan metode replace missing valuesterutama yang bertipe minimum, maximum dan zero, hasil akurasi yang didapatkan tidak terjadi perubahan yang berarti hasil akurasi sama dengan hasil akurasi tanpa dilakukan pengisian data kosong pada percobaan sebelumnya atau penggunaan ketiga teknik tersebut tidak berpengaruh terhadap perubahan akurasi.

Perbedaan terjadi ketika dilakukan percobaan menggunakan metode replace missing values bertipe average, berhasil didapatkan hasil akurasi yang berbeda sehingga teknik tersebut cocok dan sesuai untuk digunakan pada data yang akan diuji yang sebagian besar berkarakter nominal, oleh sebab itu selanjutnya metode replace missing values bertipe 
average akan digunakan pada percobaan selanjutnya.

Kemudian dari hasil pengujian juga dianalisa berdasarkan kurva ROC yang menunjukkan trade-off antara true positive rate (proporsi tuplepositif yang teridentifikasi dengan benar) dan false positive rate (proporsituple negatif yang teridentifikasi salah sebagai positif) dalam suatu model.Garis merah untuk true positif dan biru untuk thresholdseperti pada gambar 4.3 dibawah ini :

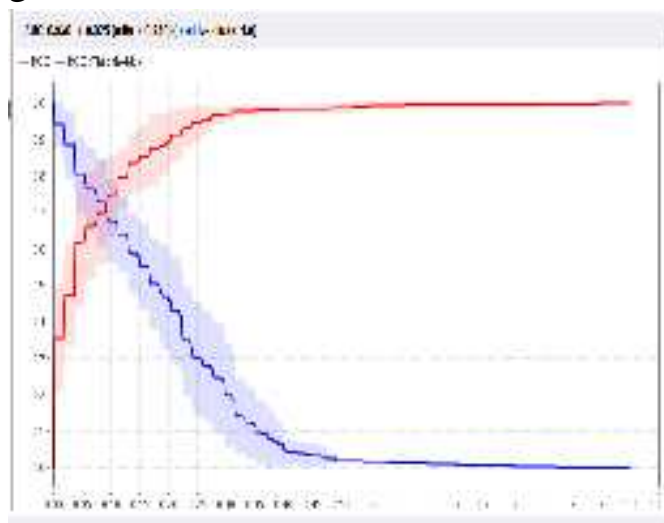

Gambar 4. 2 Kurva ROC

Menurut Gorunescu (Gorunescu, 2010) tingkat keakurasian AUC dapat diklasifikasikan menjadi lima kelompok yaitu :

1. $0.90-1.00=$ excellent classification

2. $0.80-0.90=$ good classification

3. $0.70-0.80=$ fair classification

4. $0.60-0.70=$ poor classification

5. $0.50-0.60=$ failure
Nilai AUC yang didapatkan dari pengujian berdasarkan kurva ROC menggunakan metode Naive Bayes sebesar 0.930 sehingga dari hasil tersebut berdasarkan kriteria diatas menunjukan klasifikasi yang dihasilkan termasuk kedalam kelompok excellent classification atau klasifikasi yang sangat baik.

\section{Evaluasi Dan Validasi Hasil}

Dari tabel terlihat penggunaan $X$ Validation dengan sampling type stratified memiliki tingkat akurasi yang sedikit lebih baik daripada sampling type yang lain meskipun dalam hal kehandalan klasifikasi masih sedikit lebih unggul penggunaan sampling type stratified.

Kemudian percobaan selanjutnya akan dilakukan pengujian algoritma Naive Bayesdengan teknik folds cross validationdengan pengujian data mulai 2,3,4,5,6,7,8,9 dan 10. Hasil validasi percobaan algoritma Naive Bayes tersebut

Dari hasil percobaan didapatkan pengulangan pengujian sebanyak 4 kali dengan hasil pengukuran berupa nilai rata-rata 4 kali pengujian memiliki tingkat akurasi tertinggi sebesar $86.28 \%$ dengan nilai AUC sebesar 0.940. Namun hasil dari berbagai percobaan yang ekstensif dan pembuktian teoritis, menunjukkan bahwa penggunaan 10-fold crossvalidation adalah pilihan terbaik untuk mendapatkan hasil validasi yang akurat. Hal tersebut karena 10-fold cross-validationakan mengulang pengujian sebanyak 10 kali dan hasil 
pengukuran adalah nilai rata-rata dari 10 kali pengujiansehingga dalam evaluasi hasil perbandingan performancedengan mengukur seberapa keakuratan akurasi yang dihasilkan menggunakan pengukuran 10-fold cross-validation dan pengujian performance dengan menggunakan Confusion Matrixsehingga dapat diketahui hasil akurasi dan nilai AUC untuk menentukan hasil klasifikasi kedalam klasifikasi sangat baik, klasifikasi baik, klasifikasi cukup, klasifikasi buruk dan klasifikasi salah.

Hasil akurasi yang dihasilkan sebesar $85.80 \%$ sudah cukup baik namun untuk meningkatkan hasil akurasi yang telah dihasilkan dan untuk mendapatkan penggunaan atribut terbaik maka pengujian selanjutnya dengan melakukan seleksi atribut menggunakan Naive Bayes berbasis Chi Squared.

Ketika diimplementasi menghasilkan komparasi kurva ROC seperti gambar 4.9 dibawah ini :

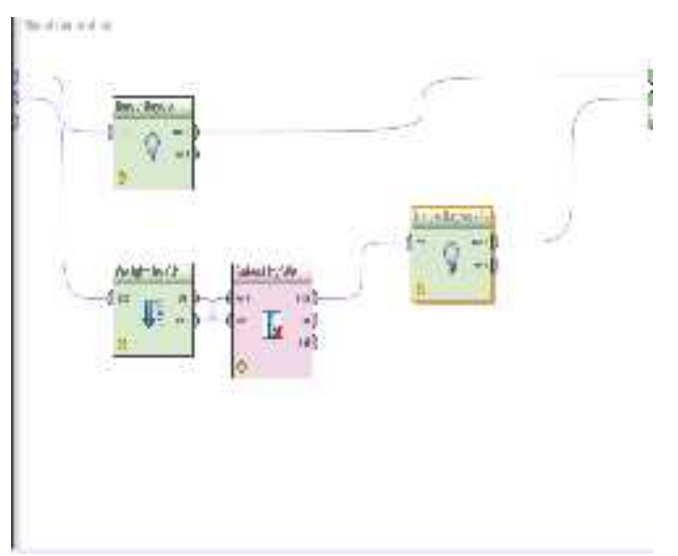

Gambar 4. 2 Model Generation Menggunakan Campare ROC

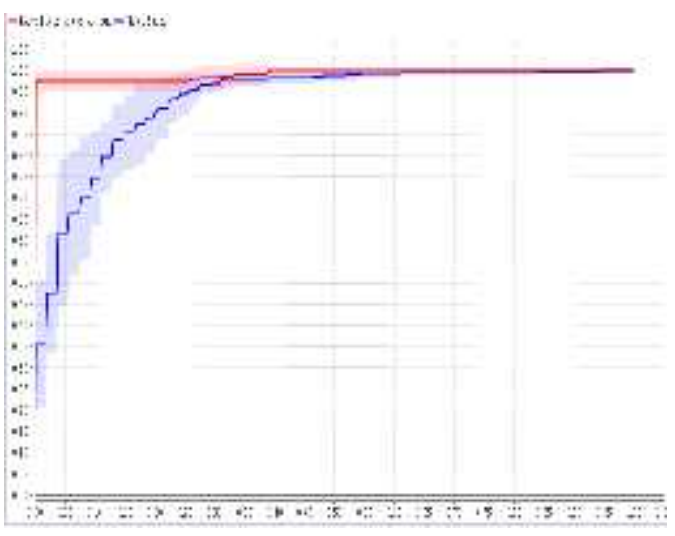

\section{Gambar 4. 3 Perbandingan Kurva ROC Menggunakan Campare ROC}

\section{Implementasi Penelitian}

Daribeberapa hasil pengujian tersebut disimpulkan bahwa algoritma Naive Bayes dalam mengklasifikasi lancar dan tidak lancar. Dengan demikian, adanya penerapan Naive Bayes mampu memberikan solusi untuk mengidentifikasi pembayarn lancar dan tidak lancar.

\section{PENUTUP DAN KESIMPULAN}

Pada penelitian ini ternyata dapat mengoptimalkan algoritma Naive Baiyes dengan pembobotan atribut terlebih dahulu sehingga akurasi dapat meningkat. Dapat dibuktikan dengan akurasi algoritma Naïve Baiyes adalah $82,19 \%$ dan untuk algoritma Naive Bayes akurasi meningkat menjadi $89,70 \%$, yang berarti akurasinya meningkat $7,51 \%$.

Sedangkan perbandingan dengan penelitian sebelumnya yaitu penelitian [10] yang menggunakan datase yang sama namun menggunakan algoritma yang berbeda yaitu algoritma C4.5 mempunyai akurasi sebesar $88,83 \%$ 
dan C4.5 memperoleh akurasi sebesar $89,26 \%$ dan untuk Naive baiyes memperoleh akurasi sebesar 82,19\% sedangkan algoritma Naive Baiyes memperoleh akurasi sebesar 89,70\%, sehingga dapat disimpulkan pada penelitian ini bahwa algoritma Naive Baiyes merupakan algoritma terbaik yang digunakan untuk memprediksi dataset pembayaran angsuran lancar dan tidak lancar yang digunakan untuk memprediksi nasabah yang berpotensi membayar angsuran Perusahaan leasing.

Penelitian ini membandingkan antara algoritma Naive Baiyes dengan Naive Baiyes, untuk penelitian selanjutnya dapat dikembangkan dengan membandingkan algortima klasifikasi lainnya seperti algoritma Support Vector Machine, Decision Tree, Neural Network, yang dapat dikombinasikan dengan algoritma optimasi lain seperti Genetic Algorithm (GA), Ant Colony Optimization (ACO), Adaboost dan algoritma optimasi yang lainnya.

\section{DAFTAR PUSTAKA}

[1] Lembaga Penjamin Simpanan, "Distribusi Simpanan Bank Umum," Lembaga Penjamin Simpanan, 2013.

[2] Dewan Perwakilan Rakyat Republik Indonesia, "UndangUndang Republik Indonesia Nomor 10 Tahun 1998," Dewan Perwakilan Rakyat Republik Indonesia, 1998.
[3] S. Y. Baswara, "Analisa Nilai Hasil Investasi Deposito Rupiah, Deposito Dolar Amerika, dan Dinar Emas Dengan Emas Sebagai Alat Ukur," Skripsi Akuntansi Universitas Diponegoro, 2012.

[4] D. T. Larose, Discovering Knowledge In Data. United States of America: John Wiley \& Sons, Inc., 2005.

[5] F. Gorunescu, Data Mining Concepts, Modelsand Techniques. Chennai, India: Springer, 2011.

[6] E. Prasetyo, Data Mining : Konsep dan Aplikasi menggunakan MATLAB, 1st ed. Yogyakarta, Indonesia: Andi, 2012.

[7] Jie Lin dan Jiankun Yu dari Yunnan University of Finance and Economics telah melakukan penelitian mengenai penggunaan Weighted Naive Bayes berbasis algoritma Particle Swarm Optimization (PSO) yang digunakan untuk pembobotan atribut

[8] Nur Aeni Widiastuti., Stefanus Santosa, Catur Supriyanto dengan judul penelitian Algoritma Klasifikasi Data 
Mining Nä̈ve Bayes Berbasis

Particle Swarm Optimization.

[9] Mutia Hafilizara dan Julio

Adisantoso. dengan penelitian

Metode Smoothing dalam

Naïve Bayes untuk Klasifikasi

Email Spam Nä̈ve Bayes

Smoothing Method for Spam

Email Classification 